\title{
THE SOCIO-COGNITIVE ASPECT OF VERBALIZATION OF JOURNALISTIC DISCOURSE ${ }^{1}$
}

Alesia Shevtsova ${ }^{2}$

\begin{abstract}
The paper focuses on the differences in the English and Russian headlines referring to the mental and contextual models of readers and journalists. The article considers the tendencies in the verbalization of the models under the influence of a concrete linguistic culture. The analysis reveals that the Russian-language headlines of articles to a greater extent actualize the ethno-specific contextual model. The title is represented by a proposition with an implication and an abstract level of description. Unlike the Russian-language headlines, the high-quality UK press is still characterized by a rather "serious" approach to presenting information in the genre of news articles. The headlines of the articles have a clear description indicating specific agents and patients of the communicative event, and also represent fairly explicit propositions. Based on the socially shared knowledge of the British epistemic community, the author actively forms a dynamic contextual model of the recipient reader by introducing new knowledge about current events and realities of modern life.
\end{abstract}

Key words: journalistic discourse, mental (semantic situational) model, contextual (pragmatic) model.

\section{Introduction}

Journalistic (or publicistic) discourse is one of the most popular and widely spread types of discourses belonging to the wider category of media discourse. Though it is the oldest and most traditional discourse, it is still the most dynamic and variable one. It always reflects the current tendencies in a specific society or in the world in general. This discourse can be viewed upon as a result of the real events through the prism of the journalist personality. Journalistic discourse is quite influential, as it can affect the recipient and persuade him or her of the perspectives chosen by the author-journalist.

1. The research was carried out within the framework of the research and development program "Trends in the development and functioning of the Belarusian-language media discourse in the context of globalization and intercultural dialogue" (State registration No. 20161437) of the subprogram "Belarusian language and literature" of the state program of research "Economy and Humanitarian Development of the Belarusian Society" for 2016-2020.

2. Assoc. Prof. PhD. Department of Romance-Germanic philology, Mogilev State University named after A. Kuleshov, Mogilev, Belarus, e-mail: shevtcova@msu.by, ORCID: 0000-0002-3041-6862 
According to the modern discursive linguistics (Cuhna, 2015; Dijk, 2016; Filliettaz \& Roulet, 2002), any language phenomenon can only obtain a complete description if it is analyzed taking into account the peculiarities of its use, all discursive aspects. This tendency of linguistic research predetermined the key role of discursive analysis and defined its position as one of the central sections of modern linguistics. At the same time, it should be noted that discourse is the object of an interdisciplinary research, including philosophy, psychology and sociology. The analysis of journalistic discourse, in particular, involves a number of extralinguistic factors: ethnocultural characteristics, social conditions of production and functioning of discourse, the focus of the journalistic discourse on a specific group of recipients, ways of managing new knowledge, which the producer adapts and integrates into their discourse, taking into account the old knowledge already possessed by the members of the epistemic community.

The socio-cognitive approach to the linguistic research emphasizes the role of knowledge in the realization of discourse. In this article, we do not consider knowledge as a universal phenomenon common to all people. We view knowledge in a narrower sense - as the knowledge of one epistemic community, which may seem to be the right or wrong opinion for another.

\section{Previous research in the field}

The factors mentioned above (ethnocultural features, social conditions for the production and functioning of discourse, the focus of journalistic discourse on a specific group of recipients, ways of managing new knowledge) relate to the main models of discourse activity proposed by T. A. van Dijk. In the course of creating journalistic discourse, there is a fact of transferring new knowledge. However, the same knowledge can be transmitted differently so that a subjective approach is observed.

As T. A. van Dijk sees it, knowledge is contextual, because "that which was accepted as the knowledge today can be rejected tomorrow as a false opinion or superstition" (Dijk, 2013, p. 6). In addition, knowledge is "assumed and taken for granted in the public discourse of the community", which is "one of the fundamental relations between discourse and knowledge" (Dijk, 2013, p. 6).

When analyzing the headlines of English-language newspaper articles, we will refer to the declarative social knowledge of the British epistemic community, according to the typology of knowledge by T. A. van Dijk. Following the aforementioned authoritative scholar, we will approach the understanding of discourse as an interpretation of the speaker's mental models, and "discourse planning means interpreting the mental model of the corresponding communicative speech activity" (Dijk, 2013, p. 7). As a part of the interpretation of newspaper headlines, there is a close interaction between the mental and 
contextual models of the author-journalist and readers. The ways of representing these models are determined by the specific pragmatic goals that the author sets.

According to T. A. van Dijk (Dijk, 2008; Dijk, 2016), the subjective situational model of the event is updated, as the addressee makes a strategic selection of the relevant information. It happens "according to the context model in the current communicative situation and taking into account the specific audience" (Dijk, 2013, p. 9). The present algorithm is implemented both in case when the texts of articles are being written and in the process of newspaper headlines creation.

Under the general influence of the context model and on the basis of the situational model, the selected relevant information is added into the semantic module, which allows to produce a significant discourse. This module mainly allows us to understand macropropositions that define the general themes of discourse and can directly influence the production of headlines (Dijk, 2013, p. 10).

The models suggested by T. A. van Dijk (2013) correlate with the modular approach to discourse analysis, the current version of which is being developed by A. Grobet (2002), L. Filliettaz and E. Roulet (2002), G. Cuhna (2015). In one of his studies G. Cuhna (2015) focuses on the complex nature of the discursive production in the case of journalistic discourse. Through the analysis, it is possible to see the complexity of decisions that a journalist must make, when he/she represents the discourses of other agents in his/her discourse. According to Simon and Nolke (as cited in Filliettaz \& Roulet, 2002), the study of complex systems is a modular methodological approach, which aims to describe the organization of the discourse and not the functioning of the mind. As G. Cuhna states

According to this methodology, initially we identify the modules entering in the composition of the discourse. A module is defined as a basic information system, which should provide a description of a specific field of discursive organization. In this approach, each dimension of the discourse is constituted of modules. Thus, lexical and syntactic modules compose the linguistic dimension; the hierarchical module constitutes the textual dimension; and the interactional and referential modules constitute the situational dimension (Cuhna, 2015).

T. Hanitzsch (2017) advances an understanding of journalistic roles as being discursively constituted and builds on the notion of journalism as a discursive institution. As the researcher states,

journalistic roles are negotiated in a relational structure - the discursive field - where journalists, news outlets, and media organizations struggle over discursive authority in conversations about journalism's identity 
and locus in society. Journalistic roles are articulated and enacted on 2 distinct levels: role orientations (normative and cognitive roles) and role performance (practiced and narrated roles). The process model of journalistic roles proposes a circular structure, where normative, cognitive, practiced, and narrated roles are connected through processes of internalization, enactment, reflection, normalization, and negotiation (Hanitzsch, 2017, p. 104).

So as we can see, the socio-cognitive approach to discourse analysis can be applied from different perspectives and it suggests a certain scope of variations, however in this particular analysis we will use the theory of socio-cognitive discourse studies suggested by T.A. van Dijk (Dijk, 2008, 2009, 2012, 2013, 2016). This research line indicates a systematic discourse analysis involving many of the typical media features, such as its characteristic overall organization, its (political) topics, or the argumentative or rhetorical strategies employed to persuasively present this 'view' to the readers (Dijk, 2016, p. 1). Alongside with the socio-cognitive approach T.A. van Dijk singles out the critical discourse studies that "typically goes beyond such a classical study of the structural properties of text or talk, and relates these structures to social structures. It may begin to identify the author(s) of the text as editors of a newspaper as a powerful media organization" (Dijk, 2016, p. 2), able to influence the opinions of hundreds of thousands of readers. However, the critical discourse studies are narrower in scale. According to T.A. van Dijk,

Sociocognitive Discourse Studies (SCDS) more broadly relates discourse structures to social structures via a complex sociocognitive interface. As in Cognitive Linguistics, it critically describes the cognitive aspects of the use of some concepts or metaphors (e.g., as expressed in inflow of foreign nationals). But more broadly, SCDS deals with the ongoing communicative Common Ground and the shared social knowledge, as well as the attitudes and ideologies, of language users as current participants of the communicative situation and as members of social groups and communities (Dijk, 2016, p. 3).

\section{Research Questions}

In the framework of this study we will focus our attention on the analysis of the headlines of newspaper articles, as they appear to be macropropositions, in which both the mental (semantic situational) model - a meaningful component of discourse, and the contextual (pragmatic) model - taking into account socially significant factors, old knowledge of recipients - are clearly realized. It should be noted that the context model of the producer and recipient in the journalistic discourse may differ. However, when creating headlines, the author focuses more on the contextual model of his/ her potential readers who, by applying general 
social knowledge, will be able to interpret the subjective situational model of the particular discourse. Special attention is paid to the communicative style of the information presentation. The hypothesis put forward is that the communicative styles in the two linguistic cultures under analysis - British and Russian - can differ and obtain specific features due to the instability of the contextual models of the recipients.

\section{Methodology and methods}

Following T. A. van Dijk (2012), we can assume that knowledge is expressed by a number of discourse structures so they possess cognitive underlying structures which should be taken into account when we analyze and describe specific properties of discourse, such as "all implicit and presupposed knowledge, as well as interactional and contextual management of old and new knowledge" (Dijk, 2011, p. 478). So, to carry out the research there is a need to use methods of discourse analysis through the lens of discursive psychology. Besides the study of cognitive personal parameters, we should consider more general social factors which predetermine our communicative behavior.

This is a truly interdisciplinary approach as for the realization of such a study we need to combine methods traditional for a linguistic research (the method of logical and comparative analysis, the elements of quantitative analysis as well as contextual analysis) with discursive techniques, independent cognitive analysis and methods of social psychology. All these are very close to the concept of critical discourse studies that relates structural properties of text to social structures (Dijk, 2016; Fairclough, 2014). N. Fairclough (2013) states that there should be 3 main aspects of analysis mapped into one another: analysis of language texts, analysis of discourse practice (text production, distribution and consumption) and analysis of discursive events as instances of socio-cultural practice.

\section{Data Analysis}

The corpus for the analysis consists of newspaper headlines from the British (The Times, The Guardian) and the Russian quality press which according to E.A. Toropova (2010) includes Kommersant, Nezavisimaya Gazeta, and Rossiyskaya Gazeta. 200 English and 200 Russian language headlines have been used to study the socio-cognitive characteristics focusing on the dominant level of description semantics.

A typical feature of some headings is the presence of a subheading - a semantically narrower sentence that concretizes and details the short but capacious heading that precedes it. At the same time, both the headline and the 
subheading can be characterized by a fairly clear description of the highlighted event. Using the terminology proposed by T. A. van Dijk (2008, 2012, 2016), in the indicated case the headlines are distinguished by a clear or medium granularity (level of description): the event is presented specifically enough by using insignificant implications or explicit propositions of the situational model, which are actualized in the journalistic discourse. At the same time some headlines can also be characterized by a rough granularity: the event is presented in a very abstract way, using implications, or implicit propositions of the situational model, which do not find direct actualization in the journalistic discourse.

The analysis of the types of description levels and peculiarities in the excerpted newspaper headlines is based on the modern approach towards the understanding of communicative styles and the difference in the information delivery in Western and Eastern cultures. T. Larina offers the term "national style of verbal communication" (Larina, 2009). This national-specific type of communicative behavior is formed under the influence of socio-cultural relations, cultural values, norms and traditions. The most important style-forming extralinguistic factor is the type of culture - British-Western or Russian-Eastern. In the construction of the utterance, in the choice of communicative strategies and language means, the speaker always finds his or her own view of the world (Larina, 2005, p. 26).

Currently, researchers are making interesting attempts to highlight communicative styles (Clyne, 1994; Gudykunst, 1990). Thus, W. Goodikunst proposed reducing all national characteristics of communication to four styles based on a dichotomous contrast: direct vs indirect, elaborate vs short (succinct), personal (personal) vs contextual (instrumental) vs affective (affective). Direct / indirect style is related to how fully and clearly in the speaker's message his / her intentions are reflected. Using a direct style of communication, the speaker expresses his / her intentions directly, while using the indirect one, on the contrary, his or her intentions are veiled, expressed indirectly (Goodikunst, 1990, pp. 27-28). Thus we can conclude, that these styles are tightly connected with the granularity (the level of description) as suggested by T.A. van Dijk.

\section{Key Findings}

As the analysis has revealed the British and Russian lingua-cultures have different semantic granularities. Most of the selected British headlines are distinguished by a clear or medium granularity (level of description): the information is stated quite clearly by using minor implications or explicit propositions of the situational model, which are actualized in journalistic discourse. Most of the selected Russian headlines are distinguished by their rough granularity: information is presented in a very abstract way, using a variety of implications, or implicit 
propositions of the situational model, which do not find direct actualization in the journalistic discourse. Since our study is comparative, it will be convenient to consider some examples of headlines in the two languages in parallel.

For example, BREXIT: UK SET FOR DECEMBER POLL AS CORBYN LIFTS LABOUR OPPOSITION TO EARLY ELECTION BILL (The Guardian, 29 Oct 2019). The article states that Jeremy Corbyn has confirmed that the Labour party will support an early election, saying the party is "totally determined" to win, to applause from members of the shadow cabinet around him. The reason for the decision was that a no-deal Brexit had been taken off the table. The title of this article is quite specific. It contains a minimum number of implications and high-level descriptions, it is informative and aims to inform the public about recent events in the political life of Great Britain. When creating this headline, the author expects the recipient to apply the general knowledge socially shared by the British epistemic community and he/ she will adequately interpret the headline presented above - for example, the proper name Jeremy Corbyn (the Labour leader). It should be noted that the headline above contains quite specific agents (the name of a specific political party) and patients (the proper name). Such a clear description contributes to the formation of clear and specific mental models. This happens if the pragmatic goal of the author-journalist is to convey accurate information to readers and inform them objectively about an event or action. This conclusion correlates with the traditional attitudes and characteristics of the quality UK press. As T.A. van Dijk notes, "accurate descriptions not only contribute to more accurate mental models of the situation, but also signal to recipients that the current fragment of the discourse is important or relevant, as if slowing down the reading and providing the deeper processing of the proposed information" (Dijk, 2013, p. 19).

\section{The Russian example ТОМАНАWК ВЕРНУЛСЯ БУМЕРАНГОМ.} Испытания наземной крылатой ракеты средней дальности в США подвели черту под историей ДРСМД ('TOMAHAWK CAME BACK AS A BOOMERANG. Tests of the medium-range ground cruise missile in the USA have drawn the line under the history of the Intermediate Range Nuclear Forces Treaty' ${ }^{3}$ - Kommersant No. 149 (6629). As in the Russian language the phrase "to come back as a boomerang" has a traditionally redefined meaning: "come back to bite/ to become a bigger problem in the future because you have not dealt with it". At the same time, a tomahawk and a boomerang have much in common in the way they look and function. So the readers at first may feel the semantic paradox and become intrigued by the headline. The English spelling of the word "tomahawk" implies that this object is somehow connected with an English-speaking country. So the general idea of the main headline is rather rough and serves as a trap to catch the reader's attention. The subheading

3. All translations of Russian examples into English are done by the author. 
following the main headline contributes to the correct interpretation of the latter by the recipient. The headline and subheading are of a local coherent sequence of propositions that are related both at the level of semantic structures and formal attributes. The abstract and even mysterious for the reader "tomahawk" is replaced by the detailed and concrete description "the medium-range ground cruise missile". The recipient's contextual model after reading the subheading is activated by the set-phrase "to draw the line" and the abbreviation "ДРСМД" widely spread in the current Russian journalistic discourse which means the Intermediate Range Nuclear Forces Treaty. The analyzed headline contains contextually new information at the end of the proposition, thus constructing the focus using the abbreviation which presents the knowledge shared by the representatives of the Russian community. At the same time the headline and even a longer and more detailed subheading are rather vague and difficult for perception by individuals from a different epistemic community. In addition to formal indicators of the local connectivity of propositions, we can establish a referential (see Givón, 2017) semantic connectivity indicating the identity of the agents and patients of a particular discourse event.

Let us discuss a few more examples: EU BEGINS PLANNING FOR TRADE NEGOTIATIONS AFTER UK AGREES TO BREXIT EXTENSION (The Guardian, 28 Oct 2019). The given headline of a newspaper article is quite specific and very informative. It does not contain any emotive words or stylistically colored means. Moreover, the author takes a neutral stand as an observer, a transmitter of factual information. The journalist makes a strategic choice of the most important relevant information in accordance with the context model in this communicative situation, addressing new knowledge to the intended circle of recipients. The target audience has a certain contextual model, which contributes to the correct "reading" of the new information. So, to interpret the above mentioned headline, you need to have an idea of the main political events in the UK, its decision and the actions being taken to exit the European Union, called Brexit. Readers are able to do this as a result of "updating the relevant elements of general social knowledge, clarifying and applying it to a specific event" (Dijk, 2013, p. 10).

It should be noted that even the most impartial author regulates the focus of a discourse event. As a rule, the focus coincides with the rheme and is placed in the final part of the headline THE RISK OF NUCLEAR WAR IS INCREASING; INVESTMENTS TO CUSHION AFRICAN COUNTRIES AGAINST CLIMATE SHOCKS NOT ENOUGH (The Times, 27 Sept 2019). In the example EXPERTS WARN WORLD "GROSSLY UNPREPARED" FOR FUTURE PANDEMICS (The Guardian, 18 Sept 2019) the headline presented summarizes the essence of the highlighted event with the rheme in the second half of the headline. The global monitoring board says that there exists a dire risk of a virulent flu pandemic which is compounded by climate 
crisis, urbanization and lack of sanitation. The author details the news, using emotionally colored lexical units (grossly unprepared, warn, pandemics). At the same time the journalist appeals to the words of the Global Preparedness Monitoring Board about the horrible scenario which is entirely plausible and efforts by governments to prepare for it are "grossly insufficient". At the moment everybody is aware of the virus COVID-19, that is, this knowledge is included in the general contextual model. Contextually, the new knowledge will be presented as an official statement about the situation in the world. Despite the stylistic expressiveness of the above headline, it is characterized by a clear description and focus on the transfer of the new knowledge to the recipient in a rather specific unambiguous form.

In some cases, the headlines of the British newspapers are so informative and specific that it seems difficult to single out one focus. For example, BRAZILIAN AMAZON DEFORESTATION SURGES TO BREAK AUGUST RECORDS (The Guardian, 27 Aug 2019). This title is intended to adjust the dynamic contextual model of the recipient - to bring new knowledge into it. Within the framework of this headline, three main epistemic blocks are semantically distinguished: there exists such a global problem as the Brazilian Amazon deforestation, it is increasing in scales, there was the highest level of it in August. All three named blocks are verbalized quite explicitly. The observation data obtained as a result of the analysis of the headlines of news articles in the British high-quality press confirm the existing traditional opinion about the "seriousness" of the information content of publications in this category of newspapers.

Let us discuss some more Russian examples: БЕНЗИН ВЫПУСТИЛ ПАР. Рост цен на топливо замедлился серьезно, но ненадолго. ('PETROLEUM HAS LET OFF STEAM. The rise in fuel prices has slowed down seriously, but not for long' - Rossiyskaya Gazeta No. 184 (7942). The main headline of the article is based on the contextual model shared by the representatives of the Russian community with the traditional phraseological unit "to let off steam". It is combined with the word "petroleum" that is not usually associated with the phrase mentioned above. The recipients feel a semantic paradox: How can gasoline let off steam? The subheading is actually reduplicating the main proposition with some extra explanations - giving the extended interpretation of the idiom under discussion: the rise in fuel prices has slowed down, but not for long. The members of the Russian epistemic community realize that when a person lets off steam, it does not mean that he or she has calmed down - it may be a temporary condition before a new emotional explosion. This type of verbalization stimulates the emotional component of the situational semantic model, intriguing the reader and encouraging him / her to read the text of the article. When creating this headline, the author expects the recipient to apply the general knowledge socially shared in the Russian-speaking epistemic 
community and adequately interpret the above headline. The reader is supposed to keep in mind that the problem of fuel prices is a really burning one and frequently discussed in Russia. The rheme here is as well as in the English examples presented in the final part of the headline and the subheading, however the level of description is quite rough.

In the Russian newspapers we find a series of headlines which contain implications based on phraseological units, anti-proverbs activated due to the existence of contextual models in the reader's mind: ИНФЛЯЦИЮ ПУСТИЛИ В РАСХОД ('INFLATION IS THROWN UNDER THE BUS' - $\underline{\text { Kommersant }}$ No. 176), В ЗДОРОВОМ ДЕЛЕ ('IN A SOUND BUSINESS' - $\underline{\text { Rossiyskaya }}$ Gazeta, No. 184 (7942). Another example is СПЕЦНА3 ОХРАНЯЛ БИЗНЕСМЕНА КАК ВЕЩЬ. ЕГо командир получил в приговоре скидку за "Норд-Ост" ('SPECIAL OPERATIONS FORCES STOOD GUARD OVER A BUSINESSMAN AS DEAD WOOD. The commander got a verdict discount for "Nord-Ost" - Kommersant No. 149). To understand this headline the reader should know a traditional redefined meaning of the word combination "как вещь" - "as a useless thing/ as dead wood". The same may be assumed about the proper name "Норд-Ост". There is an implicit reasoning in the subheading. Without the social knowledge of the historical context about the 2002 Nord-Ost siege and participants of the hostage rescue operation, the reader will not be able to understand the whole idea about the verdict discount in the subheading. So we can conclude that the key parts in the headline and subheading (which coincide with the rheme) are included in the contextual model of the Russianspeaking society and can only be deciphered by those recipients who possess a rich contextual model and are original representatives of the Russian epistemic community (Shevtsova, 2019). For a more complete construction of the mental model of the first and second propositions, the recipient needs to share a certain contextual knowledge, actualized in the discursive fragments in the final parts of the headline and subheading. Two propositions are characterized by some semantic connectors - markers that can be in cause-effect relation: special operations forces - the commander, to stand guard over a businessman as dead wood - a verdict discount. Thus, for the fullest possible interpretation of both propositions, the recipient needs to possess the general social knowledge.

\section{Conclusion}

We can conclude that the Russian-language headlines of articles to a greater extent actualize the ethno-specific contextual model. The title is represented by a proposition with an implication and an abstract level of description. Unlike the Russian-language headlines, the high-quality UK press is still characterized by a rather "serious" approach to presenting information in the genre of news articles. The headlines of the articles have a clear description indicating specific 
agents and patients of the communicative event, and also represent fairly explicit propositions. Based on the socially shared knowledge of the British epistemic community, the author actively forms a dynamic contextual model of the recipient reader by introducing new knowledge about current events and realities of modern life.

\section{Implications}

The paper is a part of a bigger study embracing data from several typologically different languages: English, Russian and Belarusian, French. The implications for future research in this field can be to extend the analysis to a greater number of other languages including Belarusian and French. An interesting perspective for the complex research will be the presentation of common and specific features in different linguo-cultures - the way the knowledge is presented, and the respective contextual and mental models activated. It will also make sense to extend the number of the excerpted materials for analysis. In this case the results would sound more convincing and significant.

\section{References:}

Clyne, M. (1994). Inter-cultural communication at work. Cultural values in discourse. Cambridge: Cambridge University Press.

Cuhna, G. (2015). The multiplicity of voices in the journalistic discourse: study of polyphony in Journalism in light of a modular perspective of discourse organization. Intercom, Rev. Bras. Ciênc. Comun, 38(2). São Paulo. Retrieved from https://www.scielo.br/scielo.php?pid=S180958442015000200159\&script=sci_arttext\&tlng=en.

Dijk, Teun A. van. (2008). Discourse and context: A sociocognitive approach. New York: Cambridge University Press.

Dijk, Teun A. van. (2009). Critical discourse studies: A sociocognitive approach. In R. Wodak \& M. Meyer (Eds.). Methods for critical discourse analysis (pp. 63-85). London: Sage.

Dijk, Teun A. van. (2011). Discourse, knowledge, power and politics. Towards critical epistemic discourse analysis. In Ch. Hart (Ed.), Critical Discourse Studies in Context and Cognition (pp. 27-63). Amsterdam: Benjamins.

Dijk, Teun A. van. (2012). A note on epistemics and discourse analysis. British Journal of Social Psychology, 51, 478-485.

Dijk, Teun A. van. (2013). Diskurs i znanye. Nauchnye vedomosti, 13(156).

Dijk, Teun A. van. (2016). Sociocognitive discourse studies. Handbook of discourse analysis. New York: Routledge. Retrieved from http://www. discourses.org/OldArticles/Sociocognitive\%20Discourse\%20Studies.pdf. 
Fairclough, N. (2013). Critical discourse analysis: The critical study of language. New York: Routledge.

Fairclough, N. (2014). Language and power. New York: Routledge.

Filliettaz, L., Roulet, E. (2002). The Geneva model of discourse analysis: An interactionist and modular approach to discourse organization. Discourse Studies, 4(3), 369-393. Thousand Oaks.

Givón, T. (2017). The grammar of referential coherence as mental processing instructions. The story of zero. Amsterdam \& Philadelphia, PA: John Benjamins.

Grobet, A. (2002). L'identification des topiques dans les dialogues. Louvain-laNeuve: Duculot.

Gudykunst, W. (1990). Culture and interpersonal communication. Interpersonal communication-8. Sage Publications.

Hanitzsch, T. (2017). Journalistic roles and the struggle over institutional identity: The discursive constitution of journalism. Communication Theory, 27(2), 115-125.

Larina, T. (2005). Natsionalnyi stil verbalnoy kommunikatsii: postanovka problemy, Vestnik RUDN, 7. Moskva: RUDN.

Larina, T. (2009). Kategoriya vezhlivosti i stil kommunikatsii: sopostavlenye angliyskih i russkih lingvokulturnyh traditsyi. Moskva: Rukopis.

Roulet, E., Filliettaz, L., \& Grobet, A. (2001). Un modèle et un instrument d'analyse de l'organisation du discours. Berne: Lang.

Shevtsova, A. (2019) Sotsyo-kognitivnyi plan verbalizatsyi russkoyazychnogo publitsisticheskogo diskursa. Sovremennyi diskurs-analiz, 3(24), 38-44.

Toropova, E. (2010). Kachestvennaya pressa kak factor formirovanya imidzha Rossii. Moskva: MGU imeni M. Lomonosova. 